\title{
Effects of gossypol on sperm counts in two inbred strains of mice
}

\author{
Suzan Hunt and Ursula Mittwoch \\ Department of Genetics and Biometry, University College London, Wolfson House, \\ 4 Stephenson Way, London NWI $2 H E, U . K$.
}

\begin{abstract}
Summary. Gossypol acetic acid was administered orally to mice of two inbred strains, BALB/c/Ola and CBA/Gr, at daily doses of 10 or $20 \mathrm{mg} / \mathrm{kg}$ for about 4 weeks. Treated mice of both strains showed a reduction in sperm counts. This was more marked in CBA mice, which also had smaller testes size than did BALB/c mice. The treatment had no significant effect on testicular weight but the caput epididymidis and seminal vesicles of treated mice weighed less than those of control mice.
\end{abstract}

\section{Introduction}

The discovery by Chinese scientists (National Coordinating Group, 1978) of a male antifertility effect of gossypol is regarded as a major lead in the search for a male contraceptive agent (Prasad \& Diczfalusy, 1982). This promise is enhanced by the findings that gossypol is not mutagenic in the Ames test (Peyster \& Wong, 1979; Majumdar et al., 1982) and does not result in chromosome damage of lymphocytes in vitro (Tsui, Creasy \& Hultén, 1983).

The original Chinese report (National Coordinating Group, 1978) stated that over $99 \%$ of men tested with gossypol $(20 \mathrm{mg} /$ day) showed necrospermia or oligospermia, usually after 2 months. Subsequent experiments suggested marked species differences in response to gossypol (Zatuchni \& Osborn, 1981). Hahn, Rusticus, Probst, Homm \& Johnson (1981) concluded that gossypol is an effective and reversible antifertility agent in rats and hamsters but not in mice. Coulson, Snell \& Parise (1980) reported that subcutaneous injections of gossypol into mice over a period of 10 days resulted in a reduction of epididymal sperm counts and reduced weights of accessory reproductive organs, whereas testicular weights remained the same or were increased. Shi \& Zhang (1980) reported that after injecting mice with a sodium salt of gossypol at $8.5 \mathrm{mg} / \mathrm{kg}$ for 4 weeks, all spermatozoa were dead and the weights of accessory organs reduced. By contrast, Wang, Luo \& Tang (1979, quoted by Prasad \& Diczfalusy, 1982) found no effect on accessory glands after treating mice with $30 \mathrm{mg}$ gossypol $/ \mathrm{kg}$ for 9 weeks.

We have investigated the effects of oral gossypol acetic acid on sperm number in mice of two inbred strains, BALB/c and CBA.

\section{Materials and Methods}

The mice used were from the inbred strains BALB/c/Ola and CBA/Gr. Male mice aged 4 or 12 weeks, from 2 or 3 litters were randomized for use as experimental or control animals. Up to 6 mice were housed in one cage, food and water being available ad libitum. At 10-14 days before the end of the experiments, each male was placed in a separate cage with a female. As fertility data are not conclusive so far, they are not included in this report. 
Gossypol acetic acid (Sigma, St Louis, MO, U.S.A.) was dissolved in absolute ethanol and diluted with 9 volumes of sunflower seed oil (Boots, Nottingham, U.K.). The solution was administered with an oral dosing needle at doses of 10 or $20 \mathrm{mg} / \mathrm{kg}$ body weight. To make up doses of 10 or $20 \mathrm{mg} / \mathrm{kg}$ respectively, 10 or $20 \mathrm{mg}$ gossypol acetic acid were dissolved in $0.5 \mathrm{ml}$ absolute ethanol to which $4.5 \mathrm{ml}$ sunflower seed oil were added. The amount of solution administered varied between 0.05 and $0.145 \mathrm{ml}$ according to body weight. Control animals were dosed with the same amounts of vehicle only. The dose was repeated 5 times a week for each mouse, the last dose being given $24 \mathrm{~h}$ before the mice were killed. Solutions were made up daily. The mice were reweighed at weekly intervals and at the end of the experiment.

Mice were killed by etherization (10:00-12:00 h). Testes, epididymides and seminal vesicles were dissected out, and freed from all surrounding tissues. Each caput epididymidis was cut off at the point of junction between caput and corpus epididymidis. All organs were weighed to the nearest $0 \cdot 01 \mathrm{mg}$.

Sperm counts were based on the method described by Searle \& Beechey (1974). The paired capita were macerated in $0.2 \mathrm{ml} \mathrm{1} \%(\mathrm{w} / \mathrm{v})$ trisodium citrate and the suspension was diluted with 2 or $4 \mathrm{ml}$ trisodium citrate, depending on caput weight. After thorough mixing, the number of spermatozoa was counted on an Improved Neubauer haemocytometer.

The statistical significance of the differences between treated and control values was tested by the following method, which avoids the complications of an analysis of variance with unequal numbers. The total sum of squares within experimental classes (i.e. strain, dosage and age combinations) was divided by the total number of degrees of freedom to give an estimate of the variance within classes, $\mathrm{Vc}$. The error variance of the difference (control - treated) for the first class $\left(\mathrm{BALB} / \mathrm{c}, 10 \mathrm{mg} / \mathrm{kg}, 4\right.$ weeks) was calculated as $\mathrm{Vc}\left(\frac{1}{4}+\frac{1}{3}\right)=0.583 \mathrm{Vc}$. The standard error was obtained from the square root of the sum of the error variances of all experimental classes; it was converted into the standard error of the mean difference for each class by dividing by 8 (number of experiments).

The error variance of the ratio $x / y$, where $x=$ treated and $y=$ control values, was obtained by using the formula

$$
\operatorname{Var}(x / y)=\frac{y^{2} \operatorname{var} x+x^{2} \operatorname{var} y}{y^{4}} ; \quad \operatorname{var} x=\frac{\mathrm{Vc}}{\mathrm{n}_{x}}, \quad \operatorname{var} y=\frac{\mathrm{Vc}}{\mathrm{n}_{y}}
$$

where $n_{x}$ and $n_{y}$ are the numbers of treated and control animals in each experimental class. As before, the standard error was obtained from the square root of the sum of the error variances of each class.

\section{Results}

The relative values of gossypol-treated mice compared with their controls are given in Table 1 . The original data are available from the authors. The two groups did not differ significantly in body weight or testicular weight, but the treated mice showed consistently lower values for weights of the caput epididymidis and seminal vesicles as well as for sperm counts. The total mean difference between caput weights of treated and control animals for all experimental classes was $9.74 \mathrm{mg}$, corresponding to a mean difference for each experiment of $1.22 \mathrm{mg}$. This has a standard error (for calculation see 'Materials and Methods') of $0.24 \mathrm{mg}$, giving a ratio of $5(P<0.001)$. For seminal vesicle weights, the mean difference for each experiment was $32.3 \pm 8.3 \mathrm{mg}$, ratio $=3.9$; and for sperm counts $960000 \pm 67000$, ratio $=14.3(P<0.001$ for both $)$.

The ratios of sperm counts of treated mice compared with their respective controls appeared to be consistently lower in CBA than in BALB/c mice. The data are summarized in Table 2. To test the significance of this difference, the summed ratios for CBA mice in Table 1 were subtracted 
Table 1. Effect of gossypol acetic acid on two inbred strains of mice

\begin{tabular}{|c|c|c|c|c|c|c|c|c|c|c|}
\hline \multirow[b]{2}{*}{ Strain } & \multirow{2}{*}{$\begin{array}{c}\text { Dosage } \\
(\mathrm{mg} / \mathrm{kg})\end{array}$} & \multirow{2}{*}{$\begin{array}{l}\text { Initial } \\
\text { age } \\
\text { (weeks) }\end{array}$} & \multirow{2}{*}{$\begin{array}{l}\text { Mean } \\
\text { duration } \\
\text { of treatment } \\
\text { (weeks) }\end{array}$} & \multicolumn{2}{|c|}{ No. of mice } & \multirow{2}{*}{$\begin{array}{l}\text { Final } \\
\text { body } \\
\text { wt }\end{array}$} & \multirow{2}{*}{$\begin{array}{c}\text { Mean } \\
\text { testis } \\
\text { wt }\end{array}$} & \multirow{2}{*}{$\begin{array}{c}\text { Mean } \\
\text { caput } \\
\text { wt }\end{array}$} & \multirow{2}{*}{$\begin{array}{l}\text { Seminal } \\
\text { vesicle } \\
\text { wt }\end{array}$} & \multirow{2}{*}{$\begin{array}{l}\text { Mean no. } \\
\text { of spermatozoa } \\
\text { per caput }\end{array}$} \\
\hline & & & & Treated & Control & & & & & \\
\hline $\mathrm{BALB} / \mathrm{c}$ & 10 & 4 & $4 \cdot 71$ & 4 & 3 & 101 & 104 & 98 & 87 & 67 \\
\hline $\mathrm{BALB} / \mathrm{c}$ & 20 & 4 & $5 \cdot 00$ & 3 & 3 & 99 & 103 & 94 & 85 & 61 \\
\hline CBA & 10 & 4 & $4 \cdot 67$ & 3 & 3 & 104 & 107 & 91 & 88 & 53 \\
\hline CBA & 20 & 4 & $4 \cdot 56$ & 4 & 5 & 91 & 106 & 79 & 71 & 34 \\
\hline $\mathrm{BALB} / \mathrm{c}$ & 10 & 12 & 4.00 & 6 & 6 & 95 & 97 & 93 & - & 64 \\
\hline $\mathrm{BALB} / \mathrm{c}$ & 20 & 12 & 4.75 & 4 & 4 & 98 & 102 & 90 & 82 & 63 \\
\hline CBA & 10 & 12 & $3 \cdot 50$ & 5 & 3 & 103 & 99 & 90 & 79 & 44 \\
\hline CBA & 20 & 12 & $3 \cdot 50$ & 6 & 4 & 99 & 104 & 87 & 90 & 38 \\
\hline
\end{tabular}

Values are expressed as $\%$ of control.

Table 2. Sperm counts in treated and control BALB/c and CBA mice

\begin{tabular}{|c|c|c|c|c|c|}
\hline & \multicolumn{2}{|c|}{ No. of mice } & \multicolumn{2}{|c|}{$\begin{array}{l}\text { Mean sperm count/caput } \\
\qquad\left(\times 10^{-6}\right)\end{array}$} & \multirow{2}{*}{$\begin{array}{c}\begin{array}{c}\text { Sperm count } \\
\text { ratio }\end{array} \\
\text { Treated/Control }\end{array}$} \\
\hline & Treated & Control & Treated & Control & \\
\hline BALB $/ \mathrm{c}$ & 17 & 16 & $1 \cdot 38$ & $2 \cdot 17$ & 0.64 \\
\hline CBA & 18 & 15 & $0 \cdot 80$ & 1.93 & 0.41 \\
\hline
\end{tabular}

from the summed ratios for $\mathrm{BALB} / \mathrm{c}$ mice. The mean difference, 0.215 had a standard error of 0.055 , giving a ratio of $3.91(P<0.001)$.

The absolute values for testis weight suggested that this was less in CBA $(53.5 \pm 1.4 \mathrm{mg}$ at 9 weeks, $54.9 \pm 1.0 \mathrm{mg}$ at 16 weeks) than in BALB/c (90.4 $\pm 1.7 \mathrm{mg}$ at 9 weeks, $111.6 \pm 1.4 \mathrm{mg}$ at 16 weeks) mice. The significance of the difference was tested with Student's $t$-test; as there was little or no difference in testis weight between treated and control mice, all experimental animals were included. The differences were significant $(P<0.001)$ for the younger $(4$ weeks at beginning of

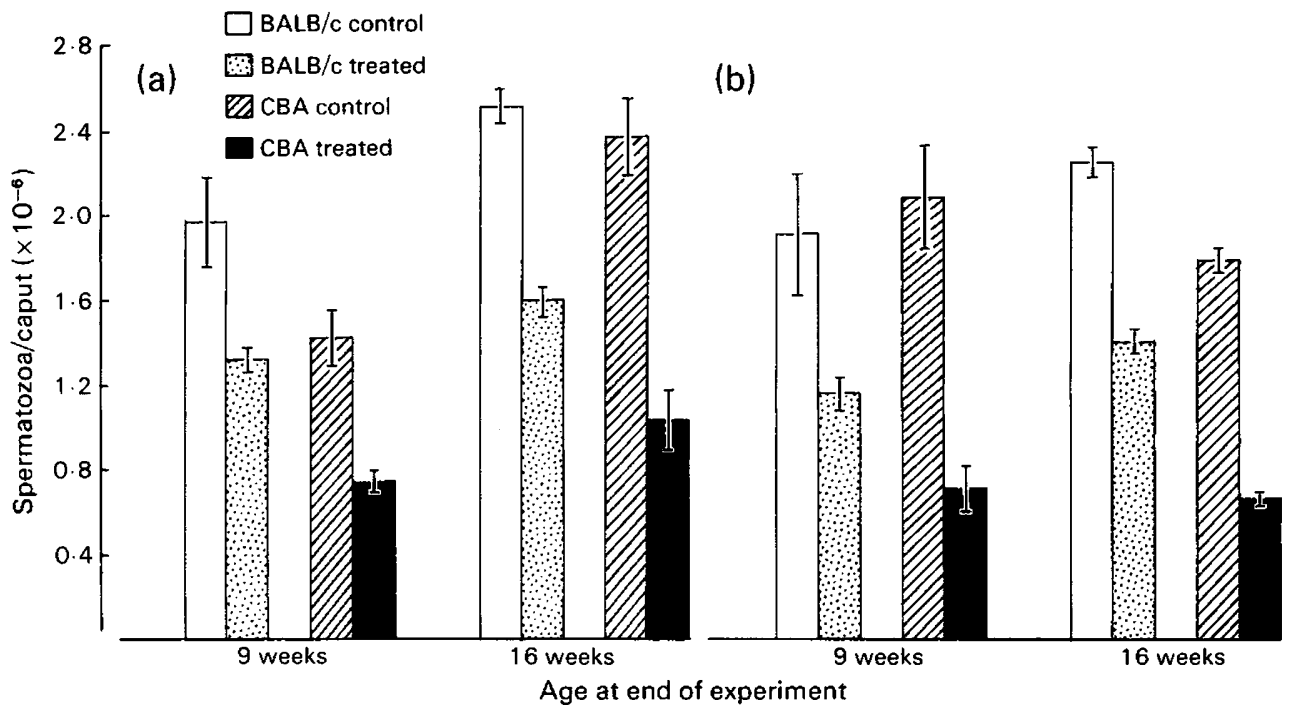

Text-fig. 1. Mean \pm s.e.m. sperm counts per caput epididymidis of mice treated with (a) $10 \mathrm{mg}$ gossypol $/ \mathrm{kg}$ and (b) $20 \mathrm{mg}$ gossypol $/ \mathrm{kg}$. 
experiment, $\left.t_{26}=12 \cdot 29\right)$ and for the older (12 weeks at beginning of experiments, $\left.t_{36}=23.45\right)$ mice.

The difference in mean sperm counts between BALB/c and CBA mice was not significant in the control group (Text-fig. 1). However, in the gossypol-treated mice, the sperm counts of CBA mice were significantly lower $(P<0.001)$ than in BALB/c mice at both ages $\left(t_{12}=4.56\right.$ for younger mice and $t_{19}=4.76$ for older mice).

\section{Discussion}

As far as we know, this is the first report for mice of a strain difference in sensitivity to gossypol. The greater reduction in sperm count seen in gossypol-treated CBA mice was paralleled by the smaller testicular size in CBA as compared with BALB/c mice. It must at present be a matter for conjecture whether there is any common biological basis linking the genetic effect giving rise to small testis size and the exogenous effect of gossypol on sperm production. Hayward \& Shire (1974) found that CBA/FaCam mice had smaller testes than did SF mice and that a large component of the difference was contributed by the $\mathrm{Y}$ chromosome.

In general, the reduction in sperm count that we observed after oral administration of gossypol acetic acid is in agreement with the findings by Coulson et al. (1980), who injected gossypol acetic acid subcutaneously. The difference in routes employed needs emphasizing, since in our preliminary experiments we found that gossypol acetic acid injected intraperitoneally was highly toxic. Mice injected with a dose of $10 \mathrm{mg} / \mathrm{kg}$ for two or three days were visibly ill and post-mortem examination revealed extreme distension of the intestines. Mice that were injected with solvent were unaffected.

Similarly, the slight decrease in the weights of eaput epididymidis and seminal vesicles of mice treated with gossypol are in agreement with the findings of Coulson et al. (1980). These authors also reported that testicular weight was either unaffected or increased after treatment; in some of our experiments a slight increase in testis weight of treated animals is suggested but the differences are not significant.

In the rat, the first cell type to be affected by gossypol is the spermatid (National Coordinating Group, 1978; Prasad \& Diczfalusy, 1982): damage to spermatids was evident after 2 weeks of treatment, and was followed by damage to pachytene spermatocytes at 3 weeks, and to leptotene and zygotene spermatocytes, as well as type B and intermediate spermatogonia at 4 weeks. Hoffer (1983) showed that at the ultrastructural level the most striking specific damage appeared to be to the mitochondrial sheath of stage 18 and 19 spermatids. If it is assumed that the sequence of events in gossypol-treated mice is similar to that in rats, it would seem likely that the major part of the reduction in sperm count that we observed is due to an effect of gossypol on spermatids. This assumption, however, needs further investigation.

The mode of action of gossypol is at present unknown. In view of its marked effect on spermatogenesis, a better understanding of its biological effect would be an important step forward in the fields of voluntary and involuntary infertility.

We thank Professor Cedric A. B. Smith for advice on statistical analysis, Dr Gillian Truslove and Mrs Diane Kyriacou for expert assistance in maintaining the mice, Mr Leslie Setterfield for skilful technical assistance and $\mathrm{Mr} \mathrm{A}$. J. Lee for the diagram. We also gratefully acknowledge an M.R.C. Research Studentship held by S.H. and financial support from the Wellcome Trust.

\section{References}

Coulson, P.B., Snell, R.L. \& Parise, C. (1980) Short term metabolic effects of the anti-fertility agent, gossypol, on various reproductive organs of male mice. Int. $J$. Androl. 3, 507-518.
Hahn, D.W., Rusticus, C., Probst, A., Homm, R. \& Johnson, A.N. (1981) Antifertility and endocrine activities of gossypol in rodents. Contraception 24, 97 105. 
Hayward, P. \& Shire, J.G.M. (1974) Y chromosome effect on adult testis size. Nature, Lond. 250, 499-500.

Hoffer, A.P. (1983) Effects of gossypol on the seminiferous epithelium in the rat: a light and electron microscope study. Biol. Reprod. 28, 1007-1020.

Majumdar, S.K., Thatcher, J.D., Dennis, E.H., Cutrone, A., Stockage, M. \& Hammond, M. (1982) Mutagenic evaluation of two male contraceptives: 5-thio-Dglucose and gossypol acetic acid. J. Hered. 73, 76-77.

National Coordinating Group on Male Antifertility Agents (1978) Gossypol-a new antifertility agent for males. Chin. Med. J. (New Series) 4, 417-428.

Peyster, A.D. \& Wong, Y.Y. (1979) Gossypol-proposed contraceptive for men passes the Ames test. New Eng. J. Med. 301, 275-276.

Prasad, M.R.N. \& Diczfalusy, E. (1982) Gossypol. Int. J. Androl., Suppl. 5, 53-70.
Searle, A.G. \& Beechey, C.V. (1974) Sperm count, egg fertilization and dominant lethality after X-irradiation of mice. Mutat. Res. 22, 63-72.

Shi, Q.X. \& Zhang, Y.G. (1980) Studies on antifertility effect of gossypol. I. Effects of gossypol on androgen dependent organs of mice and rats. Acta zool. sin. 16, $311-316$.

Tsui, Y.C., Creasy, M.R. \& Hultén, M.A. (1983) The effects of the male contraceptive agent gossypol on human lymphocytes in vitro: traditional chromosome breakage, micronuclei, sister chromatid exchange, and cell kinetics. J. med. Genet. 20, 81-85.

Zatuchni, G.I. \& Osborn, C.K. (1981) Gossypol: a possible male antifertility agent. Report of a workshop. In Research Frontiers in Fertility Regulation, Vol. 1, No. 4, pp. 1-15. Ed. G. I. Zatuchni. Northwestern University, Chicago, Illinois.

Received 11 July 1983 